\title{
LAND HOLDING AND LIVELIHOODS: A SYNTHESIS FROM MODI KHOLA
}

\section{WATERSHED, NEPAL}

\author{
Shiba Prasad Rijal, PhD \\ Department of Geography Education
}

\begin{abstract}
This paper is an attempt to analyze land holding pattern and its consequences in rural livelihoods especially of Modi Khola watershed located in Western Development Region, Nepal. The study is mainly based on primary data collected from 360 households selected randomly from Modi Khola watershed during September-October, 2002. Land is an important natural asset, has greater implications on people's livelihoods. The distribution of land among households is uneven in this area. The implications of unequal distribution and access of land can clearly be seen on household income as well as level of food sufficiency. The average household income increases with the increase in land holding size. Likewise, the percentage of household reporting sufficient food production for household consumption increases with land holding size. Thus, the well-being of local people is largely tied-up with amount of land owned by the household.
\end{abstract}

Key words: Livelihoods, land holding, land tenure, strategies, food sufficiency, capabilities, assets, wellbeing.

\section{INTRODUCTION}

Livelihoods are the means people use to support themselves, to survive and to prosper. In other words it comprises the capabilities, assets and activities for a means of living (Chambers and Conway, 1991:4). Access to different levels and combination of asset has probably the major influence on choice of livelihood options (Chambers and Conway, 1991; Scoones, 1998; DFID, 1999). However, the importance of the other factors such as capabilities of people exploiting assets and the nature of the environment can not be undermined (Pain and Lautze, 2002). The diversities in livelihoods exist by locality (Bishop, 1990; Zoomers, 1999; Subedi and Pandey, 2002; Sulivan et al., 2004; Rijal, 2006a) as a result of variation in factors mentioned above.

Land is one of the important natural assets. Efficient and wise use of land is the prerequisite for the development and prosperity of the nation. It has greater significance in livelihoods especially of backward and poor communities particularly in agrarian countries like Nepal (Sharma, 1985). In Nepal, people's livelihoods is extremely dependent on agriculture. More than 80 percent people are involved on agriculture and about 40 percent of the country's gross domestic product (GDP) depends on it (Subedi et al, 2007a: 22).

Land holding is generally an enterprise concept which involves operating of land for the purpose of producing agricultural goods ( Subedi et al., 2007a). Distribution as well as ownership of land have greater significance in determining income level. According to Subedi (1999) the economic wellbeing of majority of Nepali people is tied-up with amount of land owned by the household. Land is regarded as the means of piling of wealth and therefore any household having saving invests it in land anywhere when it is available (HLRC, 1995; Subedi et al., 2007a). Land also symbolizes social status and political power (Subedi et al, 2007a:2).

The issue of land distribution and/or land reform has remained a major concern for many decades with a view of improvement in livelihoods through agricultural development. However, the studies on livelihoods linking land is very limited. Identifying land as a basic and primary resource, Subedi et al. (2007b) realized that the poor livelihoods is due to poor status of arable land. National Planning Commission (2003) realized land fragmentation as the major hindrance for Nepalese agricultural development. Likewise, HLRC (1995) accepted land fragmentation is the major problem for modernization, commercialization and improvement in land productivity and stressed on land consolidation. In this context, the present study land holding and livelihood is timely and relevant. The purpose of this paper is to analyze landholding pattern and its consequences in rural livelihoods. The paper is organized into three sections. The first section presents general introduction along with description of the study area and the methods of the study. The subsequent second section presents discussion and findings of the study and the final section presents concluding remarks. 


\section{THE STUDY AREA}

The study area is Modi Khola watershed. It is located in the Western Development Region (Figure 1) and extends from $28^{\circ} 10^{\prime}$ North to $28^{\circ} 40^{\prime}$ North latitude and $83^{\circ} 32^{\prime}$ East to $84^{\circ} 21^{\prime} 30^{\prime \prime}$ East longitudes. It is bordered in the east by Mardi and Seti river basins, in the north by Marshyangdi basin and in the west and south by Kaligandaki basin. The total area of the watershed is 676.8 square kilometers. The elevation ranges from below $500 \mathrm{~m}$ in the south to above 8000 meters in the north within a short physical distance of about $51 \mathrm{~km}$ (Rijal, 2006b). Climate varies from warm temperate to alpine types. The area is reach in biodiversity. The upper part is important in aesthetic resources where tourism is flourished while lower part is endowed with extensive agricultural lands.

Altogether 28 Village Development Committees of three districts of Myagdi, Kaski and Parbat fall (18 entirely and 10 partially) in the Modi Khola watershed. The population within the watershed is estimated to be about $75,000(17,000$ households) in 2001 (CBS, 2002). The average family size of the watershed is 4.6 and literacy is 64.8 percent. The area is composed of different ethnic groups. The Gurung is the dominant ethnic group of the upstream part while Brahmin and Chhetri are the dominant ethnic groups in the downstream parts.

\section{STUDY METHODS}

The study is based on both primary and secondary data. The primary data was collected through household survey and group discussions with extensive field observation during SeptemberOctober, 2002. For the purpose of primary data collection, the Modi Khola watershed has been divided into two sub-regions- the upstream subregion and downstream sub-region on the basis of water regime considering the diverse environmental as well as socio-economic conditions of the study area. For this, a number of socioeconomic indicators such as literacy status, family size, distribution of land and livestock etc. were chosen and tried individually or in combination to determine the sampling units. But the basis of water regime seemed relevant and adopted for defining spatial sampling units. The dam site of the Modi Hydropower Project was considered as the dividing line for this division. All the areas lying below this limit were considered as part of the downstream sub-region and those lying upstream from this point as part of the upstream sub-region.

Altogether 12 settlements (six settlements from each sub-region) were determined for adequate coverage of the study area. A total of 360 households-180 households from each sub-region were covered for household survey. Structured questionnaire was applied for household survey. In addition 12 formal and a number of informal group discussions were organized with extensive field observation. Relevant secondary data/ information were obtained by reviewing literature and publications. The analyses is based on quantitative assessment by sub-region. Both statistical and non statistical tools are applied for data analysis. Simple correlation and Gini coefficient are applied along with some common statistical notions as statistical tools

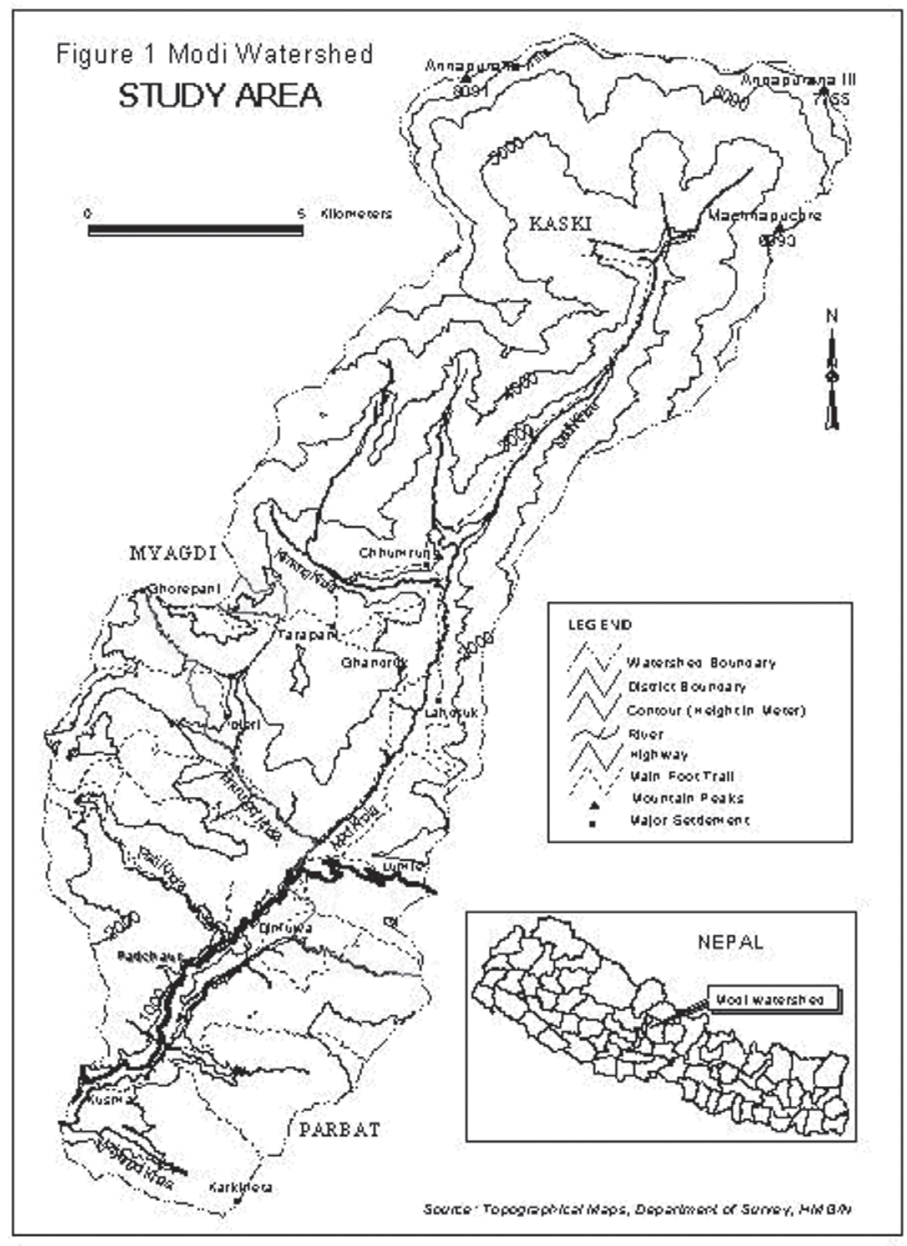




\section{LANDDISTRIBUTION}

The distribution of land among household is uneven in the Modi Khola watershed (Table 1). Out of the total 360 surveyed households, 2.2 percent distribution i.e. large proportion of land is concentrated to few households.

The average size of land holding in the study area both cropped and other lands is 1.05 ha. This is

Table 1

Percentage of households and area owned by land size categories

\begin{tabular}{|c|c|c|c|}
\hline Size of land (ha) & $\begin{array}{c}\text { Households } \\
(\mathrm{n}=360)\end{array}$ & $\begin{array}{c}\text { Area owned } \\
\text { (Total =378) }\end{array}$ & $\begin{array}{c}\text { Average size } \\
\text { (ha) }\end{array}$ \\
\hline No land & 2.2 & 0.0 & 0.00 \\
\hline Below 0.5 & 31.9 & 9.1 & 0.30 \\
\hline 0.5 to 3.0 & 60.6 & 67.5 & 1.17 \\
\hline 3.0 to 5.0 & 3.1 & 10.8 & 3.71 \\
\hline Above 5 & 2.2 & 12.6 & 5.94 \\
\hline Total & 100.0 & 100.0 & 1.05 \\
\hline
\end{tabular}

Source: Field survey, 2002/03

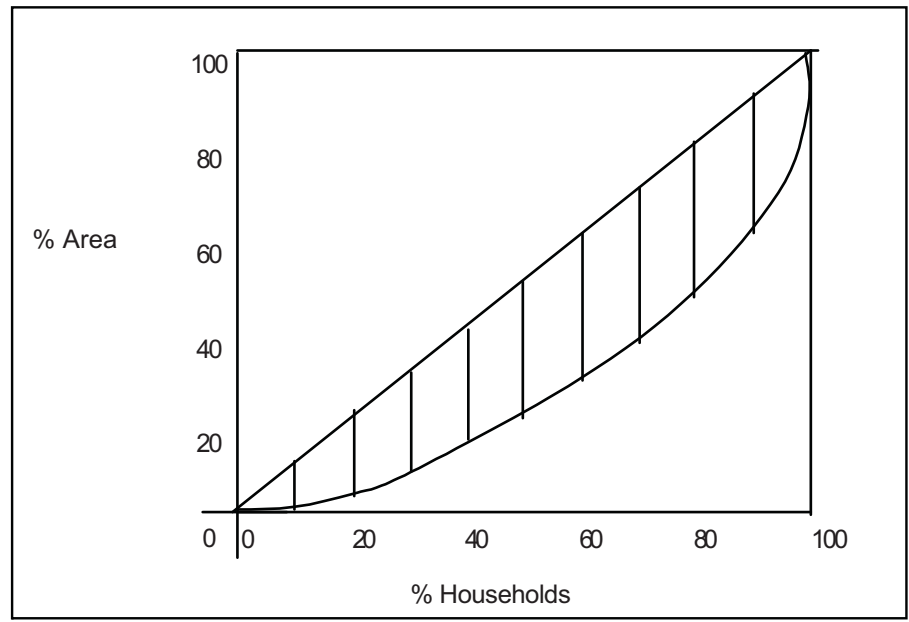

Figure 2: Land distribution between holders

households do not own lands and nearly 32 percent of the households own below 0.5 hectares of land. Majority of the households (60.6 percent) own 0.5 to 3.0 hectares of land. The proportion of households owning above 5 hectares of land is 2.2 percent. More than 23 percent of land area is occupied by 5.3 percent of households and 34 percent of households occupied only 9 percent of land. The extent of inequalities in land distribution can be shown using Lorenz curve (Figure 2) and calculating the Gini coefficient. The Gini coefficient (index) shows the degree of inequalities. The coefficient (index)varies from zero to unity- zero represents that the all households have the same area while the unity indicates the total area is concentrated to one household. The calculated Gini coefficient in this case is 0.36 . This clearly indicates the skewed bigger than that of the average national land holding size (0.83 ha), mountain (0.9 ha) and hill (0.7 ha) (CBS, 2004).

The distribution of land is uneven by sub-regions (Table 2). The proportion of households owning no land is high in the upstream sub-region (1.9 percent) as compared to the downstream subregion ( 0.3 percent). But the proportion of households owning above 5 hectares of land is high in the downstream sub-region. The proportion of households owning below 0.5 hectares, 0.5 to 3 hectares and 3 to 5 hectares of land is nearly the same in both the sub-regions. 
Table 2

Percentage of household by holding size and sub-region

\begin{tabular}{|c|c|c|c|}
\hline Size of land (ha) & Downstream & Upstream & Total \\
\hline 0.5 to 3.0 & 29.7 & 30.8 & 60.6 \\
\hline 3.0 to 5.0 & 1.9 & 1.1 & 3.1 \\
\hline
\end{tabular}

Source: Field survey, 2002/03

Out of the total land area of the watershed 19.7 percent is used for agricultural purposes. The distribution of agricultural land across sub-region is also uneven and mainly concentrated in the downstream sub-region due to favourable climate and topography. The farmland owned by households is divided into four different categories. These are khet (wet terraced land), bari (non-irrigated lands), grassland and others. The distribution of farmland by type and sub-region is given in Table 3 . sub-region. More than eight percent agricultural land is abandoned in the watershed. The proportion of abandoned land is high in upstream sub-region. Low productivity, destruction of crops by wildlife and shortage of agricultural labour are reportedly the main causes for the abandonment of farmland. Another reason for abandonment is due to shift of local people from farming to tourism and related activities.

Table 3

Types of land and its area owned by household

\begin{tabular}{|l|c|c|c|c|c|c|}
\hline \multirow{2}{*}{ Land types } & \multicolumn{2}{|c|}{ Downstream } & \multicolumn{2}{c|}{ Upstream } & \multicolumn{2}{c|}{ Total } \\
\cline { 2 - 7 } & Area (ha) & Percent & Area (ha) & Percent & Area (ha) & percent \\
\hline Khet & 98.2 & 46.8 & 57.7 & 34.3 & 159.9 & 41.3 \\
\hline Bari & 60.6 & 28.9 & 72.0 & 42.9 & 132.6 & 35.0 \\
\hline Grassland & 34.1 & 16.2 & 23.8 & 14.2 & 57.9 & 15.3 \\
\hline Others (abandoned) & 17.1 & 8.1 & 14.5 & 8.6 & 31.6 & 8.4 \\
\hline Total & 210 & 100.0 & 168 & 100.0 & 378.0 & 100.0 \\
\hline
\end{tabular}

Source: Field survey, 2002/03

Out of the total land, khet constitutes 41.3 percent followed by bari (35.1 percent), grassland (15.3 percent), and abandoned land (3.0 percent). The distribution of these lands varies by sub-region. The percentage of khet land is high in the downstream sub-region as compared to the upstream sub-region. Out of total land owned by surveyed households, khet land constitutes 46 percent in the downstream sub-region while it is 34.3 percent in the upstream sub-region. The excessive concentration of paddy land in the downstream sub-region as noted above is largely due to favorable agricultural land as controlled by climate and topography. The downstream part of the watershed is relatively flat as compared to the upstream part. The bari land is more extensive in the upstream sub-region. About 43 percent of land is under bari category in the upstream sub-region while it is nearly 29 percent in the downstream

\section{LAND OWNERSHIP}

Table 4 provides information about land ownership pattern of the study area. Nearly 98 percent (352 households) of the households own some agricultural lands. Out of the total 352 households owning land, 18.2 percent rented-out some or all of their lands to others on different contractual basis i.e. proportionate as well as fixed sharing of production (thekka). Nearly 19 percent of the total 360 households rented-in some lands from others on contract and operated together with their own lands. It is clear that some of the households having own lands also rented-in lands from others. Eight out of total 360 households do not own any lands and some of them operate others' land and some are involved only in tourism business hiring other's house. This can be seen particularly in the upstream sub-region where tourism activities are flourished. The proportion of household owning land is higher 
in the downstream sub-region as compared to the upstream sub-region. In the upstream part as a result of development of tourism activity some households are in-migrated. These households do not own any land and are involved only in tourism business.

The proportion of households both that renting-in and renting-out land is high in the upstream subregion as compared to the downstream sub-region. In this sub-region a remarkable proportion of the population are involved in tourism activities as well as different governmental and nongovernmental services elsewhere. It is to be noted cities. And a significant proportion of working age population from this zone has temporarily out migrated for job to India and abroad. Thus, their lands have been rented-out to others on contractual basis of adhiya (proportionate sharing of outputs) or thekka (fixed sharing).

\section{Land holding and livelihoods}

It has three aspects namely land as occupation base, land as a base of household income and land holding and food sufficiency. The details are discussed below.

Table 4

Household's land ownership by sub-region (in percent)

\begin{tabular}{|l|c|c|c|}
\hline Sub-region & $\begin{array}{c}\text { Owned land } \\
(\mathrm{n}=352)\end{array}$ & $\begin{array}{c}\text { Rented-in } \\
(\mathrm{n}=68)\end{array}$ & $\begin{array}{c}\text { Rented-out } \\
(\mathrm{n}=64)\end{array}$ \\
\hline Downstream & 99.4 & 11.7 & 12.8 \\
\hline Upstream & 96.1 & 26.1 & 23.7 \\
\hline
\end{tabular}

Note: Some of the households owning land also rented-in lands from others

that most of the agricultural lands of the upstream sub-region belong to the people of the upper zone. And a significant proportion of these people outmigrated from Modi Khola area to Pokhara, Kathmandu and other city areas.

Table 5 shows the land tenure status of the study area. Nearly 92 percent of agricultural land is owner operated and 8 percent is rented-in from others on different contractual basis mentioned above. The proportion of land rented-out to others is significant. More than 12 percent of the total owned

\section{Land as occupation base}

The contribution of land on livelihood is significant in determining household income as well as livelihood strategies. The people in the Modi watershed undertake a range and combination of activities in order to achieve their livelihood goals. They earn cash, food and other goods to satisfy wide variety of their needs performing different activities (Rijal, 2006b). Among activities, agriculture rank first in terms of proportion of population employed and contribution in

Table 5

Percentage of owner operated, rented-in and rented-out land

\begin{tabular}{|l|c|c|c|c|}
\hline Sub-region & $\begin{array}{c}\text { Owner operated land } \\
\text { as \% of total operated } \\
\text { land }\end{array}$ & $\begin{array}{c}\text { Rented-in land as } \\
\% \text { of total operated } \\
\text { land }\end{array}$ & $\begin{array}{c}\text { Owner operated land } \\
\text { as \% of total owned } \\
\text { land }\end{array}$ & $\begin{array}{c}\text { Rented out as \% of } \\
\text { total owned land }\end{array}$ \\
\hline Downstream & 96.6 & 3.4 & 93.1 & 6.9 \\
\hline Upstream & 86.0 & 14.0 & 80.7 & 19.3 \\
\hline Total & 91.9 & 8.1 & 87.6 & 12.4 \\
\hline
\end{tabular}

Source: Field survey, 2002/03

land have been rented-out to others. The proportion of rented-in land is higher in the upstream subregion. The main reason as noted above is the high concentration of absentee landlords in the upstream sub-region. Some people who possessed lands in this area live in Pokhara, Kathmandu and other household economy. An overwhelming majority of the population (71 percent) is involved in agriculture i.e. crop farming and livestock raising. Service in government and non-governmental agencies (within country and abroad), business, 
tourism, industrial activities, fishing and others are other occupations employed by local people. Household members adopt one or more activities to meet their needs

The importance of different activities is not similar across the watershed and varies by places as a result of variation in natural as well as socio-cultural environment, which have direct implications on choices of livelihood options. Service, business and wage labor rank second, third and fourth involving 18.9 percent, 2.8 percent and 1.6 percent population respectively. A significant proportion of population (5.6 percent) adopts other livelihood options. The community. Modi watershed is not an exception since population of this area is largely dependent on agriculture. The contribution of agriculture (including livestock) in household income is 18.0 percent. Service in governmental and nongovernmental organization, tourism, income from pension and remittances, business, and wage labor are other major sources of household income of the people of this area. Per household annual average income from different sources for the surveyed household is given in Table 7 .

The average total annual income of the surveyed household is Rs 130,354 and per capita income

Table 6

Major occupations of people of 10 years and above by sub-region (in percent)

\begin{tabular}{|l|c|c|c|}
\hline Types & $\begin{array}{c}\text { Downstream } \\
(\mathrm{n}=650)\end{array}$ & $\begin{array}{c}\text { Upstream } \\
(\mathrm{n}=626)\end{array}$ & $\begin{array}{c}\text { Total } \\
(\mathrm{n}=1276)\end{array}$ \\
\hline Agriculture & 70.8 & 71.2 & 71.0 \\
\hline Service & 21.5 & 16.1 & 18.9 \\
\hline Business & 3.1 & 2.6 & 2.8 \\
\hline Labour & 0.8 & 1.4 & 1.1 \\
\hline Sikarmi/Dakarmi & 0.2 & 1.0 & 0.5 \\
\hline Tailoring & 0.5 & 0.0 & 0.2 \\
\hline Other & 3.2 & 7.7 & 5.4 \\
\hline Total & 100.0 & 100.0 & 100.0 \\
\hline
\end{tabular}

Source: Field survey, 2002/03

other category includes tourism, different industrial activities (weaving and knitting, tailoring, brewing etc.), transport activities, fishing and collection of wild products. (family size 6.5 persons) Rs 20,054. Considering the per capita income of the hill region of Nepal for the year 2003/04 as reported in Nepal Living Standard Survey (Rs 19,823), the area shows slightly

The importance of different activities is not similar across the watershed and varies by places as a result of variation in natural as well as socio-cultural environment, which have direct implications on choices of livelihood options. Service, business and wage labor rank second, third and fourth involving 18.9 percent, 2.8 percent and 1.6 percent population respectively. A significant proportion of population (5.6 percent) adopts other livelihood options. The other category includes tourism, different industrial activities (weaving and knitting, tailoring, brewing etc.), transport activities, fishing and collection of wild products.

\section{Land as a base of household income}

Household income is largely controlled by agriculture especially of farming

Table 7

Contribution of different sources to household income

\begin{tabular}{|l|c|c|}
\hline Sources & Amount (NRs) & Percent \\
\hline Remittance & 40679 & 31.2 \\
\hline Agriculture & 23408 & 18.0 \\
\hline Service & 20918 & 16.0 \\
\hline Tourism & 13646 & 10.5 \\
\hline Pension & 10820 & 8.3 \\
\hline Business & 10557 & 8.1 \\
\hline Wage labor & 5799 & 4.4 \\
\hline Others & 4527 & 3.5 \\
\hline Total & 130354 & 100.0 \\
\hline
\end{tabular}

Source: Field survey, 2002/03 
better condition. The contribution of remittances to the total household income is 31.2 percent followed by agriculture (18.0 percent), service (16 percent), tourism (10.5 percent), and business (8.1 percent). The share of the other activities in the household income is 3.5 percent.

The average annual income of the household varies by land holding size and sub-region (Table 8 ). The table shows that the direct relationship between the size of holding and household income. The annual income of household owning no land is nearly Rs 69,000 while it is more than Rs 400,000 for households owning above 5 hectares of land. The correlation coefficient between land holding

\section{LAND HOLDING AND FOOD SUFFICIENCY}

As noted above agriculture is the main source of livelihoods of the people. More than 70 percent people of this area adopted agriculture as main occupation. Food sufficiency is the principle livelihood outcome to the households that dependent on farming. In other words, the availability of food is an indication of level of wellbeing of livelihoods especially of poor communities who depends on farming. Producing enough food for consumption is still a principle determinant of economic, social and decent livelihood status of rural households (Subedi et al.,

Table 8

Average income and percentage share of agriculture on household income (in NRs)

\begin{tabular}{|c|c|c|c|}
\hline Size of land (ha) & Downstream & Upstream & Total \\
\hline No land & 54900 & 70500 & 68550 \\
\hline Below 0.5 & 90149 & 107054 & 99998 \\
\hline 0.5 to 3.0 & 131989 & 131601 & 131757 \\
\hline 3.0 to 5.0 & 230043 & 301250 & 255936 \\
\hline Above 5 & 378133 & 536000 & 417600 \\
\hline Total household income & 132508 & 128815 & 130354 \\
Income from agriculture & 29749 & 17066 & 23407 \\
\% share on household income & 22.4 & 13.4 & 18.0 \\
\hline
\end{tabular}

Source: Field survey, 2002/03

size and household income is positive $(\mathrm{r}=0.32)$. Correlation test $(\mathrm{t}$, at $\mathrm{df}=258$ and $0.01 \propto$ level $)$ is significant. Which clearly indicates that the average annual household income increases with the increase in land holding size. The share of agriculture on total household income is 18 percent
2007). Food sufficiency status of surveyed household is shown in Table 9. Not all the households in the study area produce sufficient food for household consumption. About 44 percent of the households produce enough foods. Majority of the households (56 percent) do not produce sufficient food to meet their household annual food

Table 9

Percentage of households by food sufficiency status

\begin{tabular}{|l|c|c|c|}
\hline & Downstream & Upstream & Total \\
\hline Sufficient & 48.3 & 39.4 & 43.9 \\
\hline Insufficient & 51.7 & 60.6 & 56.1 \\
\hline Total & 100.0 & 100 & 100.0 \\
\hline
\end{tabular}

Source: Field survey, 2002/03

which varies by sub-region. The contribution of agriculture to total household income is 22.4 percent in the upstream sub-region while it is 13.4 percent in the upstream sub-region. requirements. They produce food for three to nine months only. Nearly half of them those who produce sufficient food products save and sale to others to fulfill other household requirements. 
Disparity in food sufficient is evident by sub-region in the study area. The proportion of households having sufficient food is high in the downstream sub-region as compared to that of the upstream sub-region. The proportion of households with sufficient food production is low in the higher altitudinal parts. It is mainly due to low productivity as well as low intensity of crops that controlled by environmental factors. The local people adapt a number of food deficit management practices in order to meet food deficiency. The households either manage their food deficiency through purchase of food items in local markets using earned income or borrowing of food items as well as use of wage receiving directly in terms of food items.

Size of land has greater implications in food production and food sufficiency level. No doubt, both quantity and quality of land together with use of inputs and environmental factors are equally important in food production. Size of family and hectares, 60.6 percent own 0.5 to 3.0 hectares and 2.2 percent households own above 5 hectares of land. More than 23 percent of land area is occupied by 5.3 percent of households and 34 percent of households occupied only 9 percent of land. This clearly indicates the skewed distribution and access of land. The average size of the land holding both cropped and other lands is 1.05 ha.

People of Modi Khola watershed perform diverse activities for livelihood security. The importance of these activities is not similar across the watershed and varies by places as a result of variation in natural as well as socio-cultural environment and access to assets. Among activities, agriculture rank first in terms of proportion of people employed (71 percent) and second in terms of contribution on household income (18 percent).

Livelihoods of people of this area are largely controlled by land holding size. Food sufficiency, a principle livelihood outcome and one of the

Table 10

Food sufficiency as percent of households of respected land size category

\begin{tabular}{|c|c|c|c|}
\hline Land size (ha) & Downstream & Upstream & Total \\
\hline No land & 0.0 & 0.0 & 0.0 \\
\hline Below 0.5 & 45.8 & 37.5 .1 & 41.7 \\
\hline 0.5 to 3.0 & 38.3 & 51.4 & 45.4 \\
\hline 3.0 to 5.0 & 57.1 & 75.0 & 63.6 \\
\hline Above 5 & 66.7 & - & 50.0 \\
\hline
\end{tabular}

Source: Field survey, 2002/03

food habits are other components that determine level of food sufficiency. However, in this study only size of land is considered. Percentage of households that reported sufficient food by land size category and sub-region of the study area is given in Table 10. Nearly 42 percent of households owning below 0.5 hectares of land produce sufficient food for their household requirements. Table 10 also shows the general trend that the percentage of household reporting sufficient food increases with land holding size with few exceptions. These exceptions might be due to other factors discussed above.

\section{CONCLUSION}

Land, an important natural asset, has greater implications on livelihoods. The economic wellbeing of people in the Modi Khola watershed is tied-up with amount of land owned by the household. The distribution of land among household in the Modi Khola watershed is uneven. Nearly 32 percent of the households own below 0.5 indicators of level of well-being of household especially of poor communities who depends on farming is largely guided by size of farmland. The study clearly indicates that the percentage of household reporting sufficient food increases with land holding size. The implications of land size can clearly be seen in household income too. The size of holding and household income have positive correlation. The average household income increases with the increase in land holding size.

\section{REFERENCES}

Bishop, B.C. 1990. Karnali under stress: Livelihood strategies and seasonal rhythms in a changing Nepal Himalaya. Illinois: University of Chicago.

Central Bureau of Statistics (CBS). 2004. Nepal living standards survey report 2003/04 (Statistical Report Volume Two). Kathmandu: National Planning Commission Secretariat, His Majesty's Government, Nepal. 
Central Bureau of Statistics (CBS). 2002. Population of Nepal: Village development committee/ municipalities, population census 2001-selected tables (Western Development Region). Kathmandu: National Planning Commission Secretariat, His Majesty's Government, Nepal.

Chambers, R., \& Conway, G. R. 1991. Sustainable rural livelihoods: Practical concepts for the $21^{\text {st }}$ century (Discussion Paper 296). Brigton: Institute of Development Studies (IDS).

DFID, 1999. Sustainable livelihoods guidance sheets. London: Department for International Development.

HMG/N, 2003. Economic survey, fiscal year 2002/ 03. Kathmandu: Ministry of Finance, HMG/N.

HLRC. 1995. Report of High Level Land Reform Commission (Badal Commission) 2051 (in Nepali). Kathmandu: P.B. Publication

National planning commission (NPC). 2003. Tenth Five-year Plan (2002-2007). Kathmandu: National Planning Commission.

Rijal, S. P. 2006a. Water and livelihoods in mountain areas: A case of Modi watershed, Nepal. Unpublished doctoral dissertation, Tribhuvan University, Kathmandu.

Rijal, S. P. 2006b. Livelihood strategies and income level of people of Modi watershed, Nepal. In U. M. Malla and others (eds.) The Himalayan Review (vol.XXXVII). Kathmandu: Nepal Geographical Society, pp 19-37.

Scoones, I. 1998. Sustainable rural livelihoods: A framework for analysis (Working paper 72). Brigton: Institute of Development Studies.
Sharma, C. K. 1973. Geology of Nepal. Kathmandu: Mani Ram Sharma.

Subedi, B. P. 1999. Which inequalities are greater in Nepal ? Regional or socio-economic ?: Lessons from national sample census of agriculture 1991/92. P. Sharma (ed.) The Himalayan Review (vol. XXX). Kathmandu: Nepal Geographical Society, pp 19-31.

Subedi, B. P., \& Pandey, R. 2002. Livelihood strategies of Rai communities in Arun valley: Continuity and change. In R. P. Chaudhary, B. P. Subedi, O. R. Vetaas \& T. H. Aase (eds.), Vegetation and society: Their interaction in the Himalayas, Kathmandu: Tribhuvan University, Nepal and University of Bergen, Norway.

Subedi, B. P., Subedi, V. R., Dawadi, P. P., \& Pandey, R. 2007a. Land holding pattern in mid-western Nepal.. Kathmandu: Informal Sector Service Centre (INSEC).

Subedi, B. P., Subedi, V. R., Dawadi, P. P., \& Pandey, R. 2007b. Livelihood at risk: Findings from mid-western Nepal. Kathmandu: Informal Sector Service Centre (INSEC).

Sulivan, C. A., Rijal, S. P., Shrestha, M., Khanal, N., \& O'regan, D. P. 2004. An assessment of the potential impacts of climate-induced deglaciation on communities and their livelihoods in the Hindu Kush Himalaya. (DFID KAR Project No. R7980). Wallingford: Center for Ecology and Hydrology

Zoomers, A. 1999. Linking livelihood strategies to development: Experiences from the Bolivian Andes. Amsterdam: Royal Tropical Institute. 